\title{
INTERNATIONAL LABOUR MIGRATION IN EUROPEAN RURAL REGIONS - THE EXAMPLE OF SAARLAND, GERMANY
}

\author{
Birte Nienaber, Wioletta Frys ${ }^{1}$
}

Received 17 December 2010; Accepted 23 September 2011

\begin{abstract}
International labour migration is one of the main challenges in the 21st century for rural areas within Europe. So far, rural areas have not been in the focus of research. The project DERREG, financed by EU FP7, has investigated this phenomenon. Qualitative interviews with international labour migrants have been carried out in the rural border area of Merzig-Wadern, Saarland in the South-West of Germany. The results of these interviews on motivation, working situation, professional experience, family background, social networks, future plans, satisfaction and suggestions of improvements regarding the situation of migrants show heterogeneity, in comparison with urban migrants. However, it can be concluded that the international labour migrants are a benefit to communities in rural areas if they are well integrated.
\end{abstract}

Keywords: International migration, labour migration, rural regions, integration

Kurzfassung: Internationale Arbeitsmigration ist eine der Hauptherausforderungen des 21. Jahrhunderts auch für ländliche Räume in Europa. Bisher waren ländlichen Räume nicht im Fokus der Forschung. Das Projekt DERREG, finanziert durch das 7. EU FRP, untersucht dieses Phänomen. Qualitative Interviews mit internationalen Arbeitsmigranten wurden im ländlichen Raum Merzig-Waderns im Saarland, Deutschland geführt. Die Ergebnisse der Interviews über Motivation, Arbeitssituation, Berufserfahrung, familiäre Situation, soziale Netzwerke, Zukunftspläne, Zufriedenheit und Verbesserungsvorschläge zur Situation der Migranten zeigen Unterschiede, auch zu städtischen Migranten. Es kann gefolgert werden, dass internationale Arbeitsmigranten einen Mehrwert für ländliche Gemeinschaften darstellen, wenn sie gut integriert sind.

Schlagworte: Internationale Migration, Arbeitsmigration, ländliche Räume, Integration

\section{Introduction}

In the $21^{\text {st }}$ century, one of the most important challenges in a European context is international migration. Following the discussion in media or in politics and even on an academic level, one might form the impression that migration is mainly or only a challenge for urban areas, large

\footnotetext{
${ }^{1}$ Ass. Prof. Dr. Birte Nienaber, e-mail: b.nienaber@mx.uni-saarland.de; Dr. Wioletta Frys, e-mail: w.frys@mx.unisaarland.de, Saarland University, Department of Geography, European Regional Studies, Postfach 151150, D-66041 Saarbrücken, Germany
} 
cities and the so-called megacities. The impact of international migration on rural areas in Europe has not been extensively discussed in recent times. Exceptions would include studies of second home owners (e.g. Gallent et al. 2005) and 'amenity' migration (e.g. Glorioso 2009; Mclntyre 2009). However, there is evidence for international migration into rural areas all over Europe.

Moreover, it has been identified that the European labour market needs additional workforce from abroad. This means that in the future, there will be an effort for more immigration and integration (e.g. Straubhaar 2002). These movements will not only concentrate on the larger cities, but also on rural regions. As rural regions have a socially different basis than urban regions (small settlement size, narrowness of population diversity, importance of club activities and so on) the challenge of the integration of labour migrants into rural areas is a process that cannot be ignored.

The following article will discuss what international labour migration ${ }^{2}$ into rural areas is and the characteristics of these migrants who decide to move to the countryside instead of moving to urban or even suburban areas. The article will focus on the recent situation of international labour migrants in rural Germany, differentiating between self-employed, employed and unemployed migrants. The article will present results of the case study region Saarland in South West Germany which have been achieved in the 7th EU framework project DERREG (Developing Europe's Rural Regions in the Era of Globalization).

\section{International labour migration}

“The term 'migration' refers to spatial population movements across national borders (crossborder and transnational migration), as well as inside a political-territorial, social or cultural space (internal migration)"3 (Bade et al. 2008). From a social science perspective, "the term migration generally covers spatial movements of individuals and groups of people [...] which cause a permanent change of residence" (Han 2000). Migration as a movement of people especially over large distances in geographical space is considered to be a special case of geographical mobility (Düvell 2006). On the other hand geographical mobility is the result of various flows of migration.

This article focuses on the international dimension of migration, where borders have to be crossed while migrating. However, such distinctions can be fluid. A national border can change so that suddenly a former international border disappears and international migration becomes national migration (e.g. in Germany after reunification) or borders appear and national becomes international migration (e.g. between former Yugoslavian countries) (King 2002). Moreover, moving just across the border can be easier for a migrant inside the Schengen area (the European passport-free travel zone) than moving over hundreds of kilometres inside a country. Knowing these circumstances makes international migration a complicated topic. Internal migration, however, is not in the focus of this article and is not included in the following discussion.

In academic literature, several ways of dividing international migration exist. Pries (2003), for example, explains four different types of international migration: emigration/immigration, return migration, diaspora migration and transnational migration. They have different impacts on assimilation, integration and incorporation. Figure 1 shows various types of international migration flows combined from the literature which all cause geographical mobility and have an impact on space.

\footnotetext{
${ }^{2}$ The text will use international labour migrants and international migrant workers as synonyms.

${ }^{3}$ All text passages or interviews that were originally in the German language are translated by the authors into the English language to make the text more reader-friendly.
} 


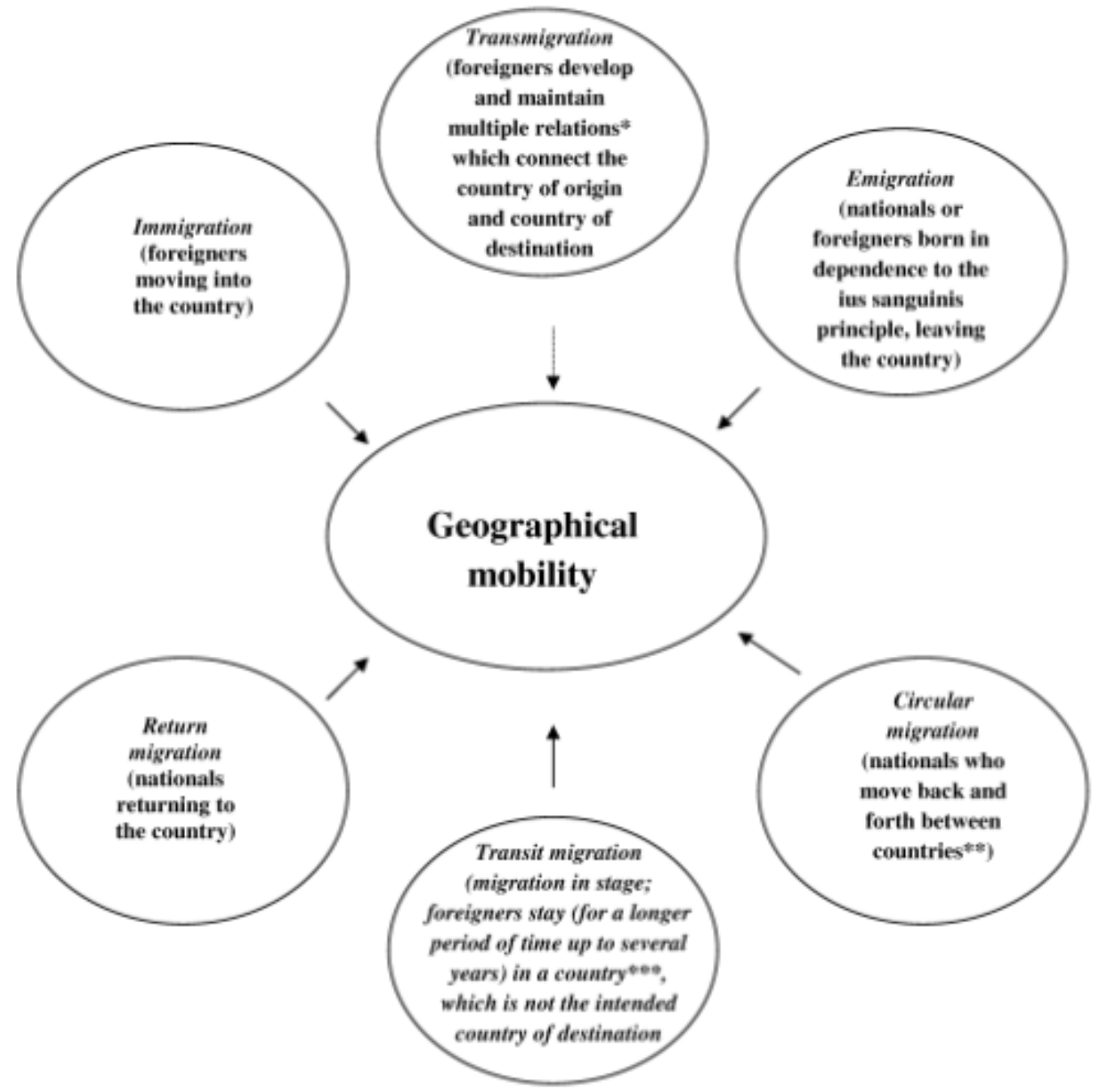

\footnotetext{
* Multiple relations can be of family, economic, social, religious, political and organisational nature.

* The movement, which implies repeated overnight stays outside the residence, is often limited by researchers to happen within a period of 30 days (e.g. Bilsborrow 1998: 5).

*.* Financial resources are gained and networks, which are important for the onward joumey, are established in the transit country.
}

Fig 1. Types of international migration flows. Source: Frys \& Nienaber 2010 adapted from Bilsborrow 1998, Düvell 2006, Glick Schiller et al. 1992, Han 2006 and Vandenbrande et al. 2006.

International labour migration has a long tradition in many European countries. It means that the main reason to move is the wish to find a job or even a better job than in the home region. Generally labour migration is deduced from a "micro-economic optimization process" (Koppel and Plünnecke 2008). Backhauset et al. (2002) consider labour wages only as fifth important for labour migration. They have established that especially in the non-academic sector mainly private motives have priority. In the academic sector the main reason to migrate can be summed up in the academic career strategies. The renown of the research institute and the academic's own status are predominant. "In the economic sector migration flows are comparatively stronger motivated by the recent differences of wages" (Koppel and Plünnecke 2008).

In the western part of Germany, labour migration is mainly based on so called "Gastarbeiter" (guest workers). Initially a shortfall in the work-force in the 1950s during the economic boom period in West Germany, led the West German government to sign recruitment contracts for workers with Italy (1955), Spain and Greece (1960), Turkey (1961), Morocco (1963), Portugal 
(1964), Tunisia (1965) and Yugoslavia (1968). The idea was that there would be a "rotation process" where migrants would come for a short period to work in Germany and then go back to their country of origin and other migrants would come. In practice, many migrants stayed in Germany. The recruitment process ended in 1973 with the oil crisis and the following economic crisis. Since the 1990s and the fall of the Berlin Wall, new groups of migrant workers have come to Germany especially from Poland, Romania and Bulgaria as well as so-called 'Spätaussiedler' (German emigrants who returned to Germany long after the end of World War II), Jewish immigrants, asylum seekers, seasonal workers, highly-skilled workers and contract workers (Haug and Rühl 2008). The population development in Germany is highly dependent on immigrants and on their fertility rate. Between 1960 and 1999 German nationals in Germany had only a low population growth of 2.5 million. Together with immigration a population growth of 9.2 million was reached (Mammey and Schwarz 2002).

Academic research in this field has a long tradition, with a wide range of theories proposed to explain migration dynamics, for example Lee's (1972) analysis of push-and-pull-factors. In more recent times, research has broadened the aspects of interest. Theories of migrant networks are one example for these new approaches:

"Migration networks shape social and spatial paths of migration, provide new migrants with information, and resources (such as residences, money, jobs), and therefore facilitate their migration. In short, they lower the costs and risks of migration. On the other hand they smooth the process of keeping in touch with the home region and influence the integration process of new migrants into the host societies. It is assumed that the accumulation of such network ties might lead to cumulative migration chains, in which the information flow from host regions to home regions stimulates further migration waves from home regions. It is not anymore the mere economic disparity between the host and the home region which induces migration, but also the existing social ties in the potential host region which facilitate migration decisions and even the positive outcome of migration for the migrant" (Nadler et al. 2010; see e.g. also Rainer and Siedler 2008).

These migration networks can be used to find a job in the region of destination and therefore are one important approach of recent migration research; however, urban areas have been the research focus so far.

\section{Methodology}

The research on rural international labour migration is a new approach. In this project 11 guideline based, qualitative interviews were carried out with international labour migrants in the district of Merzig-Wadern in the federal state of Saarland, south-west Germany. They were asked about their migratory history and exploring their motivations, experiences and intentions with regard to their life at home and abroad. This study focuses not only on migrant workers from within the EU, but also on workers from outside the EU, including Turkish and Asian workers in Germany, and the sample selected for interview reflects this heterogeneity

The sample consists of four women and seven men from the Czech Republic, Turkey, Poland, India, China, Kazakhstan, Sri Lanka and Kyrgyzstan. The respondents were aged between 27 and 46 years old and of different educational backgrounds. Regarding the fact that in Germany, the proportion of women for both in- and out-migration is smaller than that of men (40.1 per cent of all influxes in 2008, Bundesamt für Migration und Flüchtlinge BAMF 2008), a balanced purposive sample has been achieved in terms of percentages. However, the gender aspect is not the focus of this article. The interviewed persons have lived between four and twenty-five years in Germany, and are therefore all long-time migrants. Four interviewees are self-employed, the same numbers are unemployed and three employed. The self-employed workers are exploiting special ethnic niches.

The interviews took place at their homes and were recorded. The interviews were then transcribed and afterwards analysed by using qualitative text analysing guidelines. 


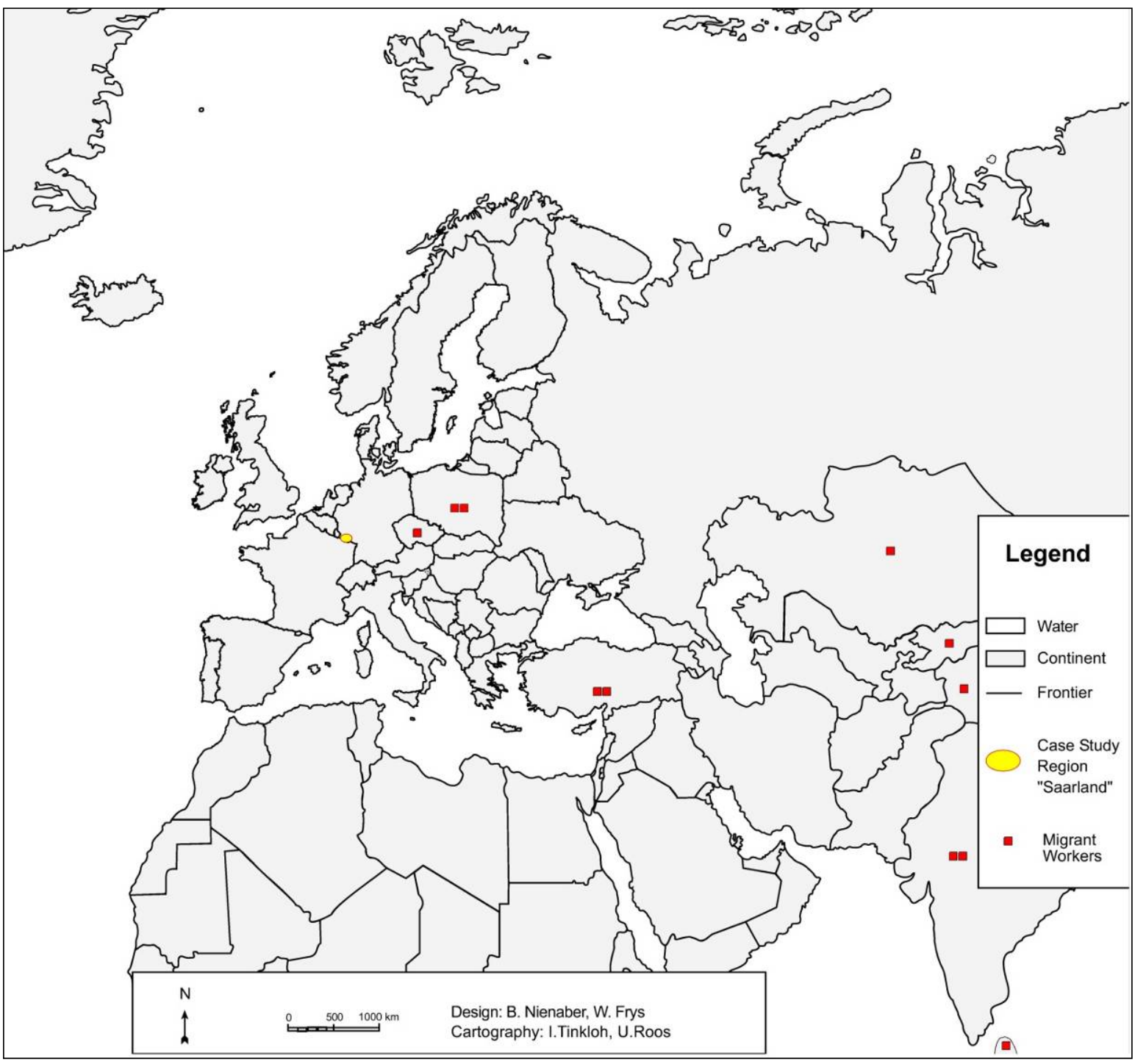

Fig 2. The countries of origin of interviewed international migrant workers in Saarland ${ }^{4}$.

The major objectives of this research on international labour migration were to investigate:

- the benefits from working across the border,

- the line of business and sector of work,

- the form of work (full time, temporary, unlimited employment...),

- plans for the future,

- integration into regional community.

"Integration" means the feeling of being integrated, so a subjective feeling of integration, as well of the integration and participation in clubs, associations and other local rural activities as all interviewed persons lived for at least four years in the case study region.

\section{Case study region: Saarland, Germany}

Saarland is the smallest of the 16 federal states of Germany (excluding city-states) with an area of 2,570 square kilometres. It has a unique history resulting from its location between French and German influence. Saarland was economically affiliated with France from 1920 to 1935 and from 1947 to 1956. Between the formation of the Federal Republic of Germany in 1949 and German reunification in 1990, Saarland was the only new state to join Germany. Saarland

\footnotetext{
${ }^{4}$ For some migrants, the move to Saarland was not the first migration step from their home country. In this graph the home countries are shown and not the last country of residence. E.g. an Indian moved from India to the Netherlands where he obtained Dutch nationality and then moved on to Germany.
} 
consists of six administrative districts: Merzig-Wadern, Sankt-Wendel, Saarlouis, Neunkirchen, Saarpfalz and Saarbrücken.

The modern Saarland economy originally developed around communities where steelworks and coal mines were located and where the workers employed in these industries lived. The decline of the coal industry is recorded in statistics that show that in $1957,65,000$ persons were employed in 18 coal mines, but by 2006 only 6,300 were left in one single mine. Not only the coal mines but also the steelworks were affected by this process of deindustrialisation (Statistische Ämter der Grossregion 2008 and Brücher et al.1982).

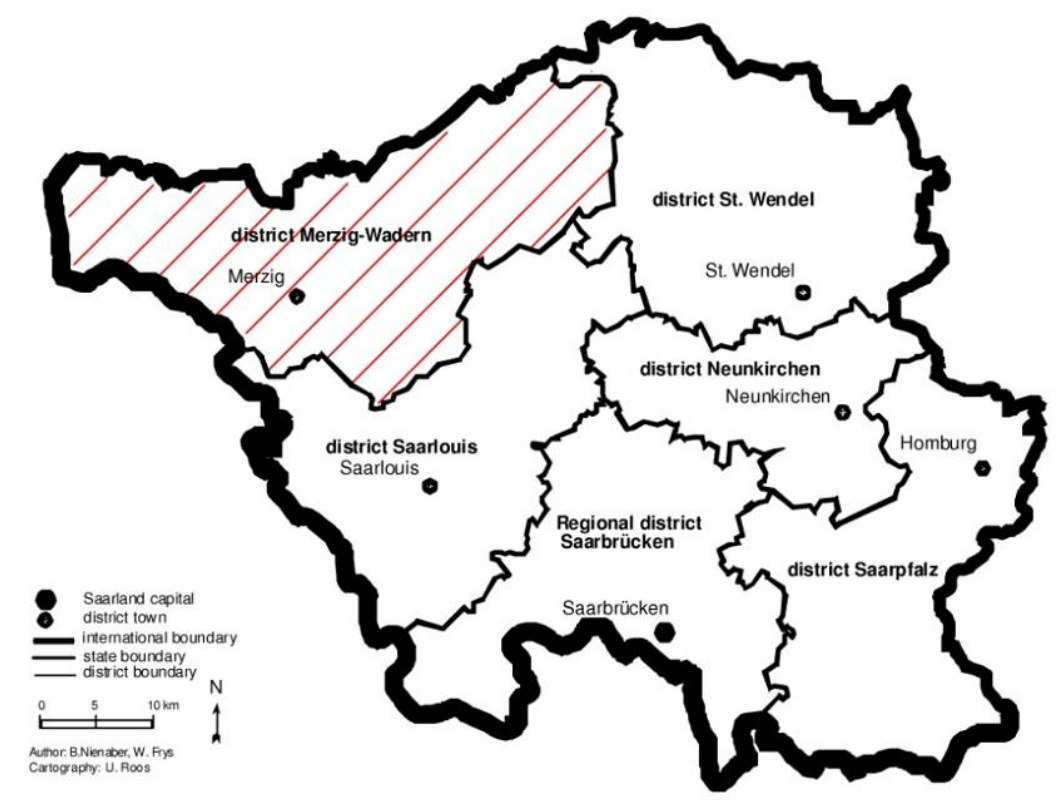

Fig 3. The case study region Saarland and the case study rural area of Merzig-Wadern.

On March 31, 2010, Saarland had a total of 1,021,101 inhabitants and 397 inhabitants per square kilometre (Statistisches Landesamt Saarland 2010). Most of the population lives in the south of the state which comprises the city of Saarbrücken and the traditional big industrial locations on the Saar River. With its capital Saarbrücken, Saarland possesses a high-order central place which has a great appeal that goes beyond its frontiers. The agglomeration areas of the federal state spread from Neunkirchen in the East to Völklingen in the West and from Saabrücken to Saarlouis and Merzig in the Northwest. Together with the Lorraine towns of Forbach, St. Avold and Sarreguemines, the region of Saarbrücken forms a cross-border agglomeration area (Geppert 2007).

The north of Saarland (Merzig-Wadern and Sankt-Wendel), and the southern part of Saarpfalz (Bliesgau) have both a lower population density than the average in Saarland. The northwestern district of Merzig-Wadern has the lowest population density in Saarland (189 inhabitants per square kilometer); Sankt Wendel has 191 inhabitants per square kilometer; and Saarpfalz has an average of 358 inhabitants per square kilometer, but this includes the oldindustrialized city of St. Ingbert. These three districts have a rural character and except for the city of St. Ingbert no large industry. Figure 3 shows the case study region and its administrative districts. The district of Merzig-Wadern represents the rural case study area for the migration research.

Besides the high population density, Saarland registers a high deficit of births over deaths (see Figure 4). The deficit of births declines together with the population density which means that the lower the population density, the lower the deficit of births is. The result is not surprising, because rural regions register higher birth rates than urban areas in Germany, but it means that migration plays less of a role in compensating for the natural decline in population in rural districts than in urban districts. 


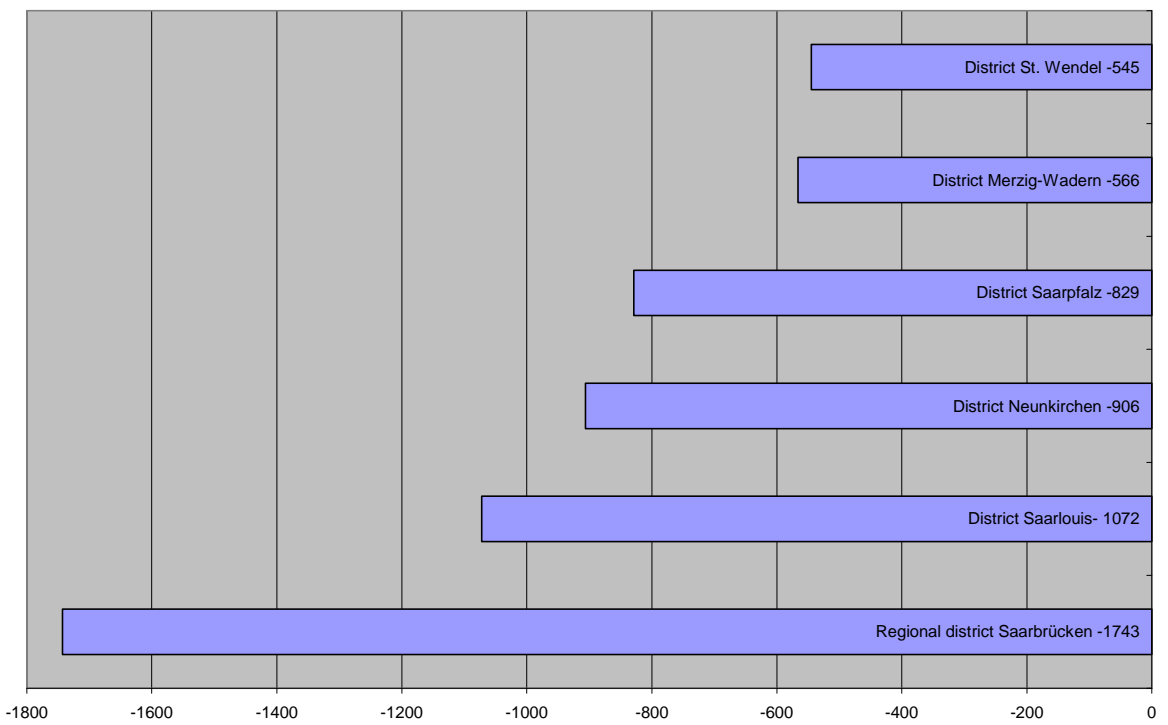

Fig 4. Deficit of births in Saarland 2009. Source: own graphic according to Statistisches Amt Saarland 2010.

'The decline in the birth rate and the migration deficit are [...] the determining tendencies for the population development and they shape the process of ageing and the decline in the population of Saarland' (ERTL 2007).

'Declining population figures and an ageing society represent an enormous challenge for Saarland. For politics and economy, this means that they have to respond to these demographical processes and to shape them' (ERTL 2007).

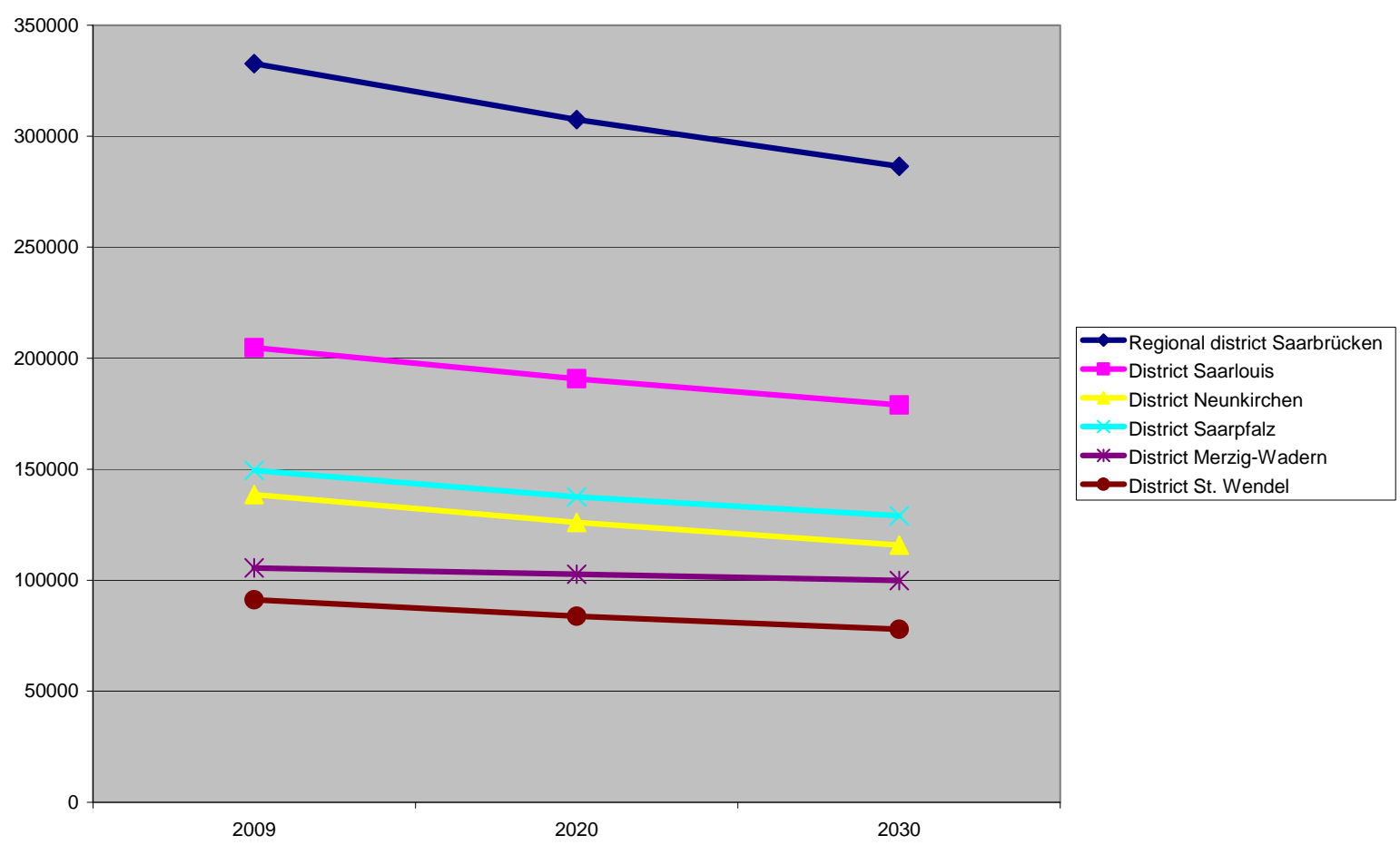

Fig 5. Forecasted population development in the districts of Saarland. Source: own graphic according to Statistisches Amt Saarland 2010.

International migration to Saarland is mainly characterised by former "Gastarbeiter" movements, by new labour migrants from Central and Eastern European countries and by cross-border migrants. The largest group of immigrants is from Italy. In 2009, there were 18,047 Italian nationals and 12,457 Turkish nationals living in Saarland. They are the largest foreign nationality group and were mainly migrating to Saarland as guest workers or as family members 
of one. The largest group coming from the CEEC $^{5}$ are the Polish nationals with 3,526 immigrants in Saarland, followed by the 1,314 Romanians. The third group are the crossborder migrants with 6,430 French and 3,384 Luxembourger (2009) (Statistisches Amt Saarland 2010).

Figure 6 shows the balance of migration which results from the movements over municipal borders. The international in- and outflows are included in these numbers. This indicates that only the urban area of Greater Saarbrücken with the state capital Saarbrücken and the rural district of Merzig-Wadern register a positive balance. Whereas Greater Saarbrücken functions as the main employer of the state and hence attracts many people from the rest of Saarland, the district of Merzig-Wadern owes its positive development to the influx of Luxembourgers.

A large proportion of migration in Saarland is comprised of cross-border migration, reflecting the close proximity to France and Luxembourg. There are two forms of cross-border migration in Saarland: in-migration from Luxembourg (mostly employees who work in highly developed south of Luxembourg) and out-migration to France (especially to rural spaces of Lorraine). Merzig-Wadern has the rural town with the highest foreign population rate inside Saarland: Perl (23.4\% foreigners of the total population, 2008). This town is located directly at the border to Luxembourg. The other rural municipalities of Merzig-Wadern have a range between $3.0 \%$ and 8.6\% foreigners of the total population in 2008 (own calculations on the basis of BertelsmannStiftung n.d.) compared to an average in whole Saarland of $7.5 \%$ (2008) (own calculation according to Statistisches Amt Saarland 2010).

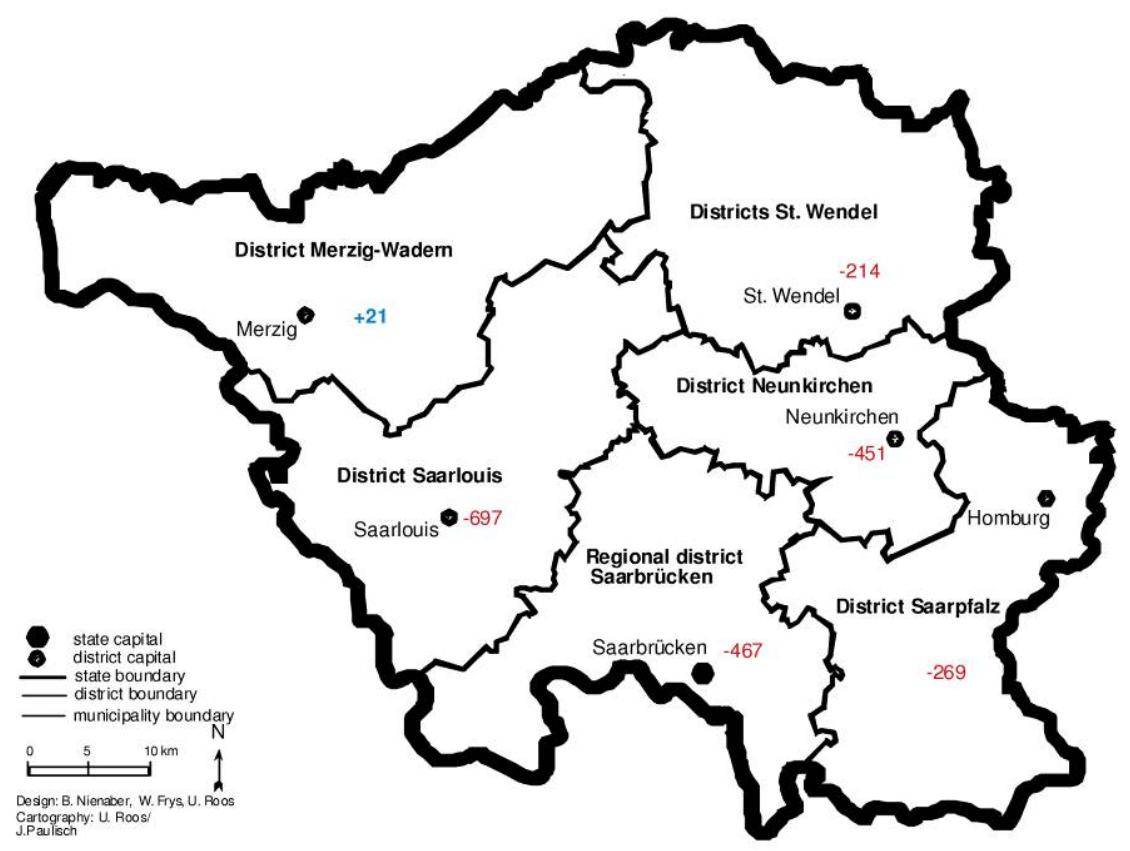

Fig 6. Balance of migration in the administrative districts of Saarland (2009). Source: own graphic according to Statistisches Amt Saarland 2010.

\section{Results of interviews}

The following discussion presents the results from interviews with international migrant workers in the district of Merzig-Wadern. It outlines their motivation to come to the region, the working situation and the professional experiences of the migrants, their social and family networks, their future plans, their satisfaction with the situation in Merzig-Wadern as well as suggestions for improvements regarding the situation of international labour migrants in the region.

\footnotetext{
${ }^{5}$ Central and East European Countries
} 


\subsection{Motivation of international migrant workers to come to the region}

The main motivation to leave their home country and to move to the district of Merzig-Wadern was the improvement of the respondent's own economic situation. This was often connected with the political situation of their home country.

'My motivation to come to Germany was the hope for a better future - simply to move to a country, where people have a higher standard of living than people in Poland at that time, in Communist Poland. Simply away from poverty and cruelty and to a better life.' (6)

'We came here, because there has been war for some time in our city and that was exhausting for us. After a year, we emigrated to Germany. At that time, emigrating as fast as possible was the only opportunity we had.' (10)

Thereby, either a job offer (4 respondents) or the desire for self-employment (one respondent) functioned as triggers for emigration. Others were looking for a suitable job only after they immigrated (six respondents).

Although not all of the respondents were employed at the time of the survey, all of them had worked in Germany since arriving in the country.

\subsection{Working situation of international migrants in the region}

At the time of the survey, four of the migrants were out of work. Six people were employed in the catering trade, three as self-employed entrepreneurs who each employed at least one other person. At least one interviewee identified the appeal of setting up their own gastronomic business as a reason for migrating to Germany (2).

A job offer was the reason for coming to Germany for four respondents. Likewise, three of the people were offered a job in the self-employed partner's business ( 1,3 and 7$)$. Another interviewee got his first job in the company where his German wife was already employed (9). Others found employment through more formal channels.

One migrant attended an integration course run by the employment office when he first arrived. In doing so, his teacher found him a job in a hotel. After a three-month internship and a training period of two years, he has become a restaurant manager (4).

Another migrant found his first employment by searching 'persistently'. After he successfully completed a language course, he asked for employment at the human resources department of a big manufacturing company. They told him that they were not recruiting and that they had to lay off employees. Nevertheless, the respondent came back two days later and asked for work again. A few days later, he asked again and he learned that they have already been thinking about him and that he should come back the following week, because they might have work for him then. The very next day, the respondent went again to the human resources department and he got employment due to his persistence and his will (5).

One person was made aware of employment in the catering trade by her neighbour. A personal above average commitment in searching for the first job could be observed here as well.

'I was married, I already had children and it was very difficult to find something. Even though there were jobs for $€ 400$ on the market. You could find something, depending on how it worked out with the children or with the whole harmony of the family. The first employment was in the catering trade as a waitress. Most of the time, I worked during weekend evenings, when my husband was at home and was looking after the children. Then, I could go working.' (6)

Despite of a lot of efforts and a great commitment to the search for work, it has not been easy and the jobs often were not satisfying. The first vocational experiences of the migrants, who found work due to their own search, were not always positive:

'For me, it was a bit difficult at that time [for the search of employment] because I could not speak German properly. [...] I have worked for half a year until the company went bankrupt. [...] For me, the second and third year was exhausting, because several times, 
I worked for temporary-employment agencies and [...] there you feel like a second-class citizen.' (10)

One respondent is a self-employed entrepreneur in the import trade and seasonally employs part-time staff. He used his personal contacts to his home country for the start-up of a small, but successful business. Concerning his job, he likes the variation, the contact with different people as well as the business trips to India and China. He enjoys being self-employed because he himself can decide about his working hours. The huge amount of work and the fact that he practically has no weekends off work represent the disadvantages of self-employment for him (8). The self-employed restaurateurs complained about a generally bad economic situation in times of the current economic crisis and about declining sales figures since the introduction of the Euro (9 and 2) or about inconvenient working hours and the little free-time connected with that (9 and 11).

'In fact, I am satisfied but at the moment [during the economic crisis] it is not so good [concerning sales figures and profit] because of the economic situation. [...] It is the same thing, every day of the year. Except of Christmas Eve, every day is the same, so that there is not much change and free-time for us.' (9)

One female migrant, working as a waitress in a restaurant, and another, employed as a saleswoman in a bakery, appreciate their employments for social reasons:

'Well, the contact to people is very important for me, with Germans as well and the cooperation with and between Germans. And thereby you can see that I am not only surrounded by foreigners and Polish, but that, in fact, I am together with Germans all the time. In doing so, I integrated myself automatically. The contact to people is certainly very close by talking to them.' (6)

One female respondent, who was out of work at the time of the survey, attended a language school, so that new and better opportunities would open up for her. She would have preferred to be employed - instead of her former employment situation as a self-employed person - in order to receive a safe salary every month. Moreover, she was dissatisfied that the wage level kept on declining: as an employee in a hotel (as a chambermaid and a breakfast waitress), she used to earn at first €7 per hour and later, only €5 for the same amount of work. She hopes that she and her husband will find better employment (7). Here, the dissatisfaction in connection with the economic situation, perceived as being bad, becomes clear.

In contrast to this, one respondent who has been unemployed since 2007, does not want to work in Germany anymore and prefers to live only on social benefits, because unemployment benefits and child allowances are absolutely sufficient for him (5).

\subsection{Professional experience of international migrant workers}

The professional knowledge that the respondents gained in their country of origin is quite different. One person, who was a self-employed entrepreneur, had been working in agriculture in his home country and then abroad in the Netherlands in the catering trade (2). Likewise, the entrepreneur with an import business is a trained carpenter, but he had already worked as a baker and a gardener, before he started his own business (8). One entrepreneur in the catering trade had already worked in the building industry (11), whereas another selfemployed restaurateur is a trained car mechanic and has a college degree in technology and then came to Germany (9). The professional experiences of the employees were described as follows.

One respondent, who was employed as a waitress, also worked in the catering trade in her home country. After her final secondary-school examinations, she trained to work in a hotel. Before she came to Germany, she worked as an au-pair girl in England (1). Another waitress worked as a cook and a seamstress in her home country (3). Generally, the respondents' occupational status in their home countries was not satisfying, as the following statement indicates: 
'I finished school in Poland by passing my final secondary-school examinations and then came the political change. And that was very bad from the political and economic point of view: inflation, no jobs and privatizations. People didn't know themselves, where they are and who they are. Later on, many schools didn't make sense anymore. In communism, they made sense and they had a purpose but in the meantime, they've become insignificant. However, my father found something in the private sector. Together with my father, I had a share in it. Apart from that, I hadn't got a job in the public sector, where I used to work. From the political side, it simply wasn't possible.' (6)

The migrants, who were unemployed at the time of the survey, had already gained professional experience both in their home country and the case study region. Likewise, one of the respondents, a trained electrician, used to work in this job in his home country as a start after he completed training. As an adolescent, he also worked as a seasonal farm labourer in the former Czechoslovakia. In the district of Merzig-Wadern, he had worked as a factory employee for a big manufacturing company for 17 years. In 2007, he was laid off for making comments defaming Germany (5).

Another unemployed respondent, who completed her training in order to become a seamstress in her home country, was employed in Germany (in the catering trade) as well as self-employed with a restaurant (7).

A young job-seeker accepted his first employment at the age of 14 in his home country. He worked as a croupier in a casino. Then, he became manager of the casino. Moreover, he completed his studies and received a degree in tourism. In the district of Merzig-Wadern, he worked as a restaurant manager until the restaurant had to be sold (4).

Another unemployed interviewee completed his training in order to be a car mechanic and he used to work in construction industry (10).

\subsection{Family background and social networks of international migrants}

Concerning their family background, the respondents differ very much from each other. Therefore, only significant characteristics of integration are paid attention to in the following.

One of the employees travelled to Germany alone. Before she came to the district of MerzigWadern, she did not know anyone. In the meantime, she has built up a circle of friends, which mainly consists of locals, particularly of colleagues (1). Another one followed her husband, who has opened up a fast food stall. She also did not know anyone before she moved to the district of Merzig-Wadern. Only her husband had relatives and acquaintances in the region. For the time being, she was not able to establish a circle of friends, but her husband had, which predominantly consists of migrants from Turkey (3). Yet another female migrant came to Germany alone, but she already knew some people here, who originated from her home country. Now, due to her children, she has a very large circle of friends and acquaintances, which is composed of Germans as well as of migrants (6). None of the employees was a member in a club.

Two brothers and the mother of one of the self-employed respondents also work in the district of Merzig-Wadern. One brother has a circle of friends which mainly consists of German locals from his village. Additionally, he is a member of a football and handball club (8). Another one came to Germany without his family and got to know his German wife here. His circle of friends is composed of Germans as well as of other migrants (9). He himself and the other two selfemployed respondents are not members in a club $(2,9,11)$. One self-employed respondent took his family with him from his home country, whereas the members of his family had no influence on the decision process concerning the move to Germany. His current circle of friends primarily consists of self-employed migrants (2). Another interviewee came with his wife and one child to the region, where they had five more children. Today, he lives together with his wife and five of the children in his own house. He has a mixed circle of friends, which is composed of Germans and migrants (11).

Concerning social life, the unemployed respondents were not inactive. One of them came from Kazakhstan with his parents to the district of Merzig-Wadern. His parents also live in the region. 
Before they moved to Saarland, they already knew some relatives, who live in Saarland, too. He has a circle of friends which consists of Germans and migrants. Moreover, he founded a club for adolescents originating from Russia in autumn 2009. Until now, almost all of the members came from Russia, but the club is open to other nationalities as well (4). The circle of friends of another unemployed person is primarily composed of Germans (7), whereas the delicate statement of one interviewee, who received German citizenship in the meantime, testifies his distancing from social networks in the case study region and a difficult family background:

'I am not German [...] I have no German roots. [For me] many other countries came into consideration, for example Great Britain, America and France. After all, I met a [...] woman and came to know that she had German citizenship, a so-called permit number. Then, I married her and left with her to settle down in the West. I wanted to get divorced from the girl, but then it appeared that we're going to have a child. So I stayed.' (5)

Only one of the interviewees was a member in a local club (8), however, another one founded a club for migrants (4). Indeed, the respondent's children were often members in clubs.

\subsection{Future plans of international migrants}

In general, the migrants do not plan to leave the district of Merzig-Wadern. However, many of them make their future plans conditional upon their partners' plans or their own working situation $(1,3,9)$. Likewise, one of the respondents who is currently unemployed could imagine moving to another federal state or to Luxembourg, for example, for employment reasons (10). One female migrant, who has children of school age, does not want to leave the district in any event as long as her children are still in school (6).

One self-employed migrant described how he wants to have a second home in his home country and live there temporarily after retirement. He could imagine changing his whereabouts every three months. However, moving to another federal state would not be an opportunity for him, because, in Saarland and in his village, he feels perfectly integrated and gets along very well with the people there (8).

Most of the migrants generally want to stay in the case study region and they do not articulate plans for change, particularly as some of them $(7,11)$ own a house in the region by now. Only one interviewee wished to move away soon to Wiesbaden or Mainz, larger German cities, where he has friends (4).

\subsection{Satisfaction of migrants with overall situation in the region}

In general, the self-employed people are very satisfied with the situation in the region. Only one of the interviewees complained about the political situation in Saarland and - according to him the problems, which are connected to that, namely the wait to receive citizenship that he applied for years ago.

One of the self-employed restaurateurs would find an urban environment more pleasant than the rural one of the district of Merzig-Wadern, because then distances would not be that great. Moreover, he thinks that the administration of foreign nationals in Saarland is impersonal and complicated:

'That is really the only thing which causes difficulties for us from time to time. The situation with the administration of foreign nationals here in Saarland is simply much too complicated, inconvenient and much too impersonal.' (9)

Another respondent appreciates his life in a rural environment, although he criticises the poor public transport connection, which makes the possession of a car indispensable (8).

However two of the three employees describe their satisfaction as average, and all of the unemployed respondents express their general satisfaction with their situation in the region. One reason for this could be the certainty that there is no better situation in the home country they left: 
'If people are dissatisfied they can easily go back to their home country. I have already been here in Saarland for almost six years.' (4)

'I've got my friends here, here's my determined residence.' (10)

One of the respondents needs to get used to this rural life, because he is from a large city. Nevertheless, he likes the landscape as well as the living quality. The location of the MerzigWadern district at the border triangle is very pleasant to him, as he has a lot of possibilities for trips with his family. Furthermore, he feels accepted by the locals and he is glad that there is no nationalism in the region. However, he regrets that there is no large city nearby (4). Another female migrant appreciates the fresh air in her rural environment (7).

\subsection{Suggestions for improvements regarding the situation of migrant workers in the region}

All of the interviewees were asked about suggestions for the improvement of the situation of migrant workers in the district of Merzig-Wadern. While one of the respondents did not give any information (11), the others made suggestions for improvement.

One interviewee thinks that the city of Merzig and the local employment office are already doing a lot for migrant workers, providing language courses and support searching for a job (4).

Three respondents $(5,7,10)$ contended that the wages of migrant workers should be brought into line with the wages of the locals.

'Sometimes in Germany, migrants who come here directly get a job and people who were born in German, can't get a job, because the migrants are paid worse and of course, that's better for the business manager. That is definitely a big disadvantage. For migrants, the working situation isn't good in general.' (10)

Other migrant workers $(2,3,5,6)$ wish for better working conditions and a larger spectrum of job offers or better language assistance:

'Foreigners should get more opportunities to find work more easily or to learn more at a language school. There should be more possibilities for foreigners.' (3)

One of the respondents thinks that bureaucracy should be made easier and that the waiting period for migrants concerning their naturalisation should be shortened (8), whereas another person does not see any differences between migrants and locals, concerning the difficult situation on the job market, and only criticises the authority for foreign nationals:

'The only thing, which is maybe a bit more difficult, is the authority for foreign nationals. That's a bit awkward. You have to wait such a long time and they're very unfriendly there.' (1)

An Indian migrant worker suggested founding a country-specific culture association which would organise events and celebrations for everybody who is interested:

'In fact, I'm from North Rhine-Westphalia and what strikes me is that we had a lot of cultural associations for all kinds of nations: Italians, Spanish, they all had their own club. These associations also had a restaurant which was open for everybody and they organised a lot among themselves, celebrations, for example, but they did it for everybody. Something like that doesn't even exist here. (...) What I saw, but which isn't there anymore, was a Turkish meeting place in the pedestrian precinct. And that was really the only thing l've seen so far in this area. And only Turkish people actually went there, not one single German. This custom of inviting each other does not take place.' (9)

\section{International migrant workers as a benefit for rural development?}

Summing up, it can be stated that the migrant workers in the case study region are generally satisfied with their life. Even those who were unemployed at the time of the survey, do not plan to move away (except for one person). The difficult situation on the job market is regretted, however, it is considered to be a circumstance which affects everyone and, to some extent, as 
a consequence of the current economic crisis. Problems are only recognised concerning language, the poor public transport in Saarland and long distances as there is no big city near the district of Merzig-Wadern. The closest larger cities from the municipality of Perl in MerzigWadern are Luxembourg (88,586 inhabitants, $40 \mathrm{~km})$, Trier in Rhineland-Palatinate, Germany $(104,640$ inhabitants, $44 \mathrm{~km})$ and Saarbrücken (176,749 inhabitants (2009), 64 km) (Statistische Ämter der Großregion 2010 and own calculations). By comparing the perception of the situation by the migrants and the real situation, the perception might be an indicator for a mental barrier caused by language problems, as well as a poor public transport situation, but also of a life focussed on the rural surrounding and a distance overcoming problem.

The main reasons for arriving were the political situation at home, the social security schemes and employment. This coincides with the findings of Koppel and Plünnecke (2008) and Backhaus et al. (2002) that wages are not seen as a priority motivation to migrate. This is also underlined by the statements of respondents that they are employed in a so called ' $€ 400$ job', low wage jobs in Saarland.

It can also be seen that the potential that is brought by the professional background of the migrants is not used positively by the rural region. The migrants rather have a different vocational training than the current job is. Looking at the lack of a qualified workforce, using these capabilities might be a chance to enhance the endogenous development of rural areas.

Another potential can be seen through better integration of the migrants into rural life. In the German countryside, club activities (e.g. volunteer fire brigades, sport clubs, musical societies, shooting clubs) are very important for the communal life. The interviewed migrants, however, are very poorly connected to this social aspect of the rural area. Only one respondent is a member in a local club and one has established a club for migrants. Migrant children are in fact better integrated into local clubs. A better integration of the migrants into these rural activities and networks can have an impact of enhancement on the rural life and support endogenous rural development. The interviewees were, however, well integrated into the rural society more broadly having mixed German and migrant friends.

Most of the respondents enjoy the countryside. Other regions are not seen to offer better chances; the respondents do not even see opportunities for a better work life in an urban area (except for one person). The respondents appreciate rural regions for the fresh air and the easier integration into the local population.

To enhance rural development and to use the capabilities of the migrants for the labour market as well as for the social rural life, some improvements should be made: equality of migrants on the labour market, more language assistants and courses in rural areas, less bureaucracy and more integration into local activities. This is reinforced by the fieldwork evidence whereby some interviewed people are unemployed because of these problems. The employed interviewees complain about unfair wages in comparison to the locals. Moreover, for some migrants only the self-employment seemed to hold a future chance, as they then can work instead of being unemployed as well as offer special (ethnic) niche products.

Overall, international labour migrants can be very important for rural areas in the future if the potential of their living in the countryside is fully recognised and positively engaged.

References

[1] Backhaus, B., Ninke, L. \& Over, A. (2002). Brain Drain - Brain Gain. Eine Untersuchung über internationale Berufskarrieren. Retrieved from: http://www.stifterverband.info/ publikationen_und_podcasts/positionen_dokumentationen/braindrain_braingain_2002.pdf (4.11.2010).

[2] Bade, K. J., Emmer, P. C., Lucassen, L. \& Oltmer, J. (2008, Eds.). Enzyklopädie Migration in Europa: Vom 17. Jahrhundert bis zur Gegenwart. $2^{\text {nd }}$ ed. Paderborn: Ferdinand Schöningh Verlag. 
[3] Bertelsmann-Stiftung (Ed.) (n.d.): Demographiebericht. Daten - Prognosen. Gütersloh: Verlag Bertelsmann-Stiftung.

[4] Bilsborrow, R. E. (1998). The state of the art. In Bilsborrow, R. E. (Ed.), Migration, Urbanization and Development: New Directions and Issues (pp. 1-56). Norwell, Dordrecht: Kluwer.

[5] Brücher, W., Quasten, H. \& F. Reitel, F. (Eds.) (1982). Pilotstudie zu einem Saar-Lor-LuxAtlas. In: Schriftenreihe der Regionalkommission Saarland-Lothringen-LuxemburgRheinland-Pfalz, Vol. 8. Saarbrücken, Metz, Luxembourg, Trier.

[6] Bundesamt für Migration und Flüchtlinge - BAMF (Ed.) (2008). Migrationsbericht des Bundesamtes für Migration und Flüchtlinge im Auftrag der Bundesregierung (Migrationsbericht 2008). Nürnberg.

[7] Düvell, F. (2006). Europäische und internationale Migration. Einführung in historische, soziologische und politische Analysen. In Liebert, U. \& J. Falke (Eds.), Europäisierung. Beiträge zur transnationalen Europadebatte, Vol. 5, Hamburg.

[8] Ertl, D. (2007). Bevölkerungsentwicklung 2006: Stärkster Bevölkerungsrückgang seit 1978. In: Statistisches Quartalsheft Saarland, No. III/2007.

[9] Gallent, N., Mace, A. \& Tewdwr-Jones, M. (2005). Second Homes. European Perspectives and UK Policies. Aldershot: Ashgate.

[10] Geppert, J. (2007). Regionalprofil Saar-Lor-Lux-Rheinland-Pfalz. Großrosseln.

[11] Glick Schiller, N., Basch, L. \& Blanc-Szanton, C. (1992). Transnationalism: a new analytic framework for understanding migration. In Glick Schiller, N., Basch, L. \& Blanc-Szanton, C. (Eds.), Toward a Transnational Perspective on Migration (pp. 1-24). New York: New York Academy of Sciences.

[12] Glorioso, R. S. (2009). Managing Amenity Migration: The Role of Multiple Future Scenarios. Die Erde, 140(3), 293-315.

[13] Han, P. (2000). Soziologie der Migration: Erklärungsmodelle, Fakten, Politische Konsequenzen, Perspektiven. Stuttgart: UTB.

[14] Han, P. (2006): Theorien zur internationalen Migration. Ausgewählte interdisziplinäre Migrationstheorien und deren zentralen Aussagen, Stuttgart: UTB.

[15] Haug, S. \& Rühl, S. (2008). Remigration von Zuwanderern in Deutschland. Geographische Rundschau, 60(6), 26-33.

[16] King, R. (2002). Towards a New Mapping of European Migration. International Journal of Population Geography 8(2), 89-106. Doi: 10.1002/ijpg.246.

[17] Koppel, O. \& Plünnecke, A. (2008). Braingain - Braindrain. Die Wachstumspotenziale der Zuwanderung. Köln: Deutscher Instituts-Verlag.

[18] Lee, E. S. (1972). Eine Theorie der Wanderung. In Szell, G. (Ed.), Regionale Mobilität, (pp. 115-129). München: Nymphenburger Verlagshandlung.

[19] Mammey, U. \& Schwarz, K. (2002). The demographic characteristics of immigrant population in Germany. In Haug, W., Compton, P. \& Courbage, Y. (Eds.), The demographic characteristics of immigrant population (pp. 193-244). Strasbourg: Council of Europe.

[20] McIntyre, N. (2009). Rethinking Amenity Migration: Integrating Mobility, Lifestyle and Social-Ecological Systems. Die Erde, 140(3), 229-250.

[21] Nadler, R., Burdack, J. \& Kriszan, M. (2010). International mobility and migration of rural population. Unpublished report. Leipzig: Institut für Länderkunde.

[22] Pries, L. (2003). Transnationalismus, Migration und Inkorporation. Herausforderungen an raum- und Sozialwissenschaften. Geographische Revue 2, 23-39. 
[23] Rainer, R. \& Siedler, T. (2008). Social networks in determining migration and labour market outcomes: Evidence from the German Reunification. In ISER Working Papers, No. 36/2008.

[24] Statistische Ämter der Großregion (2008, ed.). Saar-Lor-Lux-Rheinland-Pfalz-Wallonie Statistiques en bref 2006. Statistische Kurzinformationen 2008. Saarbrücken, Nancy, Luxemburg, Bad Ems, Namur.

[25] Statistische Ämter der Großregion (2010) Statistiken der Großregion. Gesamtbevölkerung. www.grossregion.lu/pages/StatTemplate.aspx?view=stat\&id=621 (04.11.2010).

[26] Statistisches Amt Saarland (2010). Statistik: Grafiken, Tabellen und Artikel. http://www.saarland.de/6772.htm (04.11.2010).

[27] Straubhaar, Th. (2002). Migration im 21. Jahrhundert, Tübingen: Mohr Siebeck.

[28] Vandenbrande T. et al. (2006). Mobility in Europe. Analysis of the 2005 Eurobarometer survey on geographical and labour market mobility (= European Foundation for the Improvement of Living and Working Conditions). 